\title{
The Influence of Electronic Commerce on the Traditional Trade of Our Country
}

\author{
Kang Liu \\ Jiangxi industry polytechnic college, Department of Economics and Management
}

Keywords: Traditional Industry; E-Commerce; Countermeasure

\begin{abstract}
In recent years, with the rapid development of Internet technology, to further promote the maturity and improvement of E-Commerce, but also greatly expanded the scope of E-Commerce services and applications. The rapid development of the electronic commerce industry has greatly changed the economic and social operation mode. In the traditional industries, there are problems such as rising costs, excess capacity, supply and demand imbalance, rapid growth of production, the contradiction between supply and demand, and so on. For accelerating the pace of introduction of electronic commerce mode of traditional industries, should continuously improve positioning and understanding of E-Commerce, comprehensively promote the electronic commerce application and popularization, and actively create the development environment of the electronic commerce credit and accelerating the establishment of e-commerce talent team, which effectively solve the traditional industry development dilemma.
\end{abstract}

\section{Introduction}

The rapid development of the Internet makes knowledge and information spread widely, and it has intensified the trend of homogenization of products and services. The increasingly fierce market competition, forcing companies to find new business platform and method to create new opportunities for development, and improve the quality of service. Therefore, more and more social entities actively using the Internet to carry on the commercial and business activities, personal use of the Internet easy to meet their individual needs, enterprises use the Internet across the region to buy raw materials and sell goods. These realities of demand and action, not only accelerated the development of e-commerce, but also greatly expanded the types of e-commerce services and applications, to promote more types of business activities can be carried out online.

Among them, the traditional industries are faced with GDP growth slowdown, rising labor costs and new economic and new industries and other factors. All kinds of crisis forced the traditional industries have joined the ranks of electronic commerce in the, such as Suning, the Gome, they keenly perceived only cater to the Internet this big trend to from the fierce competition in the market get more benefits. But throughout China's traditional industry after the introduction of E-Commerce operations, the results are not optimistic, the survival of the fittest in the market, the traditional industry in the operation of a good E-Commerce sites are very few.

E- Commerce

E-Commerce in recent years to flourish in the world, but the concept of "E-Commerce" there are a variety of explanations:

1. E-Commerce refers to the use of electronic networks to carry out business activities.

2. E-Commerce refers to the realization of electronic. From the scope of the coverage can be defined as: the parties to electronic transactions rather than face-to-face exchanges or direct face-to-face exchange or any form of business transactions; From technical aspects can be defined as: E-Commerce is a collection of techniques, including exchange of data (such as electronic data exchange, E-mail), access to data (shared database, electronic bulletin boards) and automatic data capture (bar code).

3. E-Commerce is a business activity that is carried out by electronic means. It processes and transmits data electronically, including text, sound, and images. It covers many aspects of the activities, including goods electronic trade and services, online data transfer, electronic funds 
transfer, electronic stock trading, electronic shipping documents, commercial auction, cooperative design and engineering, online information, public products.

\section{The Dilemma of the Introduction of Electronic Business Model in the Traditional Industry}

The Difference between the Traditional Industry and the Electronic Commerce Operation Mode. In the traditional industries, the retail and manufacturing industries usually take the terminal mode of operation; Daily necessities, industrial supplies and electrical appliances and other commodities are usually used in the way of distribution channels, that is, through the wholesale distribution of goods at all levels of distributors to retailers; The remaining relatively simple shops generally take extensive mode of operation. The traditional marketing model is strictly dependent upon layers of channels, and requires a lot of people to compete for market share. E-Commerce and the traditional industry has a very different operational essence.

The Channel Integration of Traditional Industry Line Channels Difficult. In the traditional sales channels, the basic model is the Manufacturer - Dealers - Consumers, manufacturers through the dealers at all levels will be delivered to the hands of consumers. Electronic business model automatically shortens the sales link, can make the manufacturer directly to consumers. In addition, a lot of companies to take online and offline differentiated pricing strategy, which is easy to make the brand's credibility has been questioned by customers. Therefore, the rational integration of corporate online and offline channels, the interests of the balance between channels is the main problem to be solved in the traditional industry to introduce electronic business model.

Decision Makers Lack the Determination to Challenge Themselves. Many entrepreneurs focus on competing products and channels, but ignore the user's needs and feedback. At the same time, in the enterprise internal operation process, the enterprise managers' self-protection consciousness is strong, will not take the initiative to undertake the enterprise in the electronic commerce domain strategy innovation the duty; If managers tend to the traditional part of the electricity business sector, once the conflict occurs, it will face a difficult dilemma, only to take more short-term behavior, and the operation of the idea of electronic commerce runs counter to.

\section{The Traditional Industry into E-Commerce Solutions}

Constantly Improve the Positioning and Understanding of E-Commerce. Develop enterprise e-commerce development strategy, clear differences between the traditional sales model and e-commerce business model, analysis where e-commerce industry growth of online business trend, research and discrimination existing and potential competitors in the electronic commerce strategy, reasonable planning sales channel system, channel balance between the distribution of benefits to determine reasonable development goals. Enterprises to define their own e-commerce platform positioning, namely should comply with the characteristics of the industry, and enterprise business philosophy, operational capability and commodity characteristics fit, so that customers can in the shortest possible time seize the enterprises to transfer to the core idea of target consumers.

Fully Promote the Application and Popularization of Electronic Commerce. Continuous deepening of the application of electronic commerce in large enterprises. Promote large-scale industrial enterprises in e-commerce application, to promote the interactive development of entity and network marketing channels, improve cooperation level of the enterprises and suppliers, to achieve enterprise procurement, manufacturing, sales, production and operation of collaborative operation, so that the production and operation of the process to the online trading, logistics and distribution, credit payment integration trend. Encourage large commercial enterprises to use e-commerce to expand distribution channels and market space. Encourage large retail enterprises to carry out network marketing pilot.

Actively Create a Good Environment for the Development of Electronic Commerce. To strengthen the public service and market supervision of electronic commerce in the public service, promote the convergence of e-government and e-commerce, to provide more effective services for enterprises. To promote the opening of government information resources according to law, 
improve the social and market development and utilization level, and improve the public service environment of electronic commerce. In the market supervision, especially supervision network management is the main network trading platform to strengthen self-discipline, law-abiding, fulfill the responsibility for maintaining the market order of electronic commerce.

\section{Conclusion}

The rise of electronic commerce has changed the business environment, especially the traditional industries. Electronic commerce to subvert the traditional business model of the industry, the user of electronic commerce has become an important war to determine the traditional industry and the life and death. Traditional industries need to face up to the problems existed in its business operation, decision makers need to change of enterprise operating concept, the formation of professional business team, from the operation channel, and so the overall change to cater to the operation mode of electronic commerce. Traditional industry wants to do e-commerce was not built in a day, but as long as the master of electronic commerce operation rules and patterns, can be found in new opportunities and business opportunities.

\section{References}

[1] Freedman, Craig. "Insider's story: notes on the Claire Friedland and George Stigler partnership..." History of Economics Review 55(2012):324-328.

[2] Lin F R, Huang S H, Lin S C. Effects of information sharing on supply chain performance in electronic commerce[J]. Engineering Management IEEE Transactions on, 2002, 49(3):258-268.

[3] Madeja N, Schoder D. Impact of Electronic Commerce Customer Relationship Management on Corporate Success - Results from an Empirical Investigation. [C]// Hawaii International Conference on System Sciences. 2003:181b.

[4] Rico D F. Effects of agile methods on website quality for electronic commerce[J]. Dissertations \& Theses - Gradworks, 2007:464-464.

[5] Chou T H, Chien C C, Yeh T Y. Using the Intelligent Agent on the Telecom Electronic Commerce Website[C]// Web Intelligence, 2004. WI 2004. Proceedings. IEEE/WIC/ACM International Conference on. 2004:644-647.

[6] Rofiq A, Mula J M, Scott A. Purchase Intention to Undertake E-Commerce Transactions in Developing Countries: Application of Theory of Planned Behavior in Indonesia[C]// Management and Service Science (MASS), 2011 International Conference on. IEEE, 2011:1-4.

[7] Aries Susanto H T, Chang Y. Determinants of initial trust formation in electronic commerce acceptance in Indonesia[C]// Systems, Process and Control (ICSPC), 2014 IEEE Conference on. IEEE, 2014:96 - 100.

[8] Wang Y, Wang J. Research on tourism development strategy and patterns of vacation islands in China: Case study of Weizhou Island[C]// Artificial Intelligence, Management Science and Electronic Commerce (AIMSEC), 2011 2nd International Conference on. IEEE, 2011:3317-3320.

[9] Li B. The Superiority and problems analysis on the application of the equator principles by China's commercial banks[C]// Artificial Intelligence, Management Science and Electronic Commerce (AIMSEC), 2011 2nd International Conference on. IEEE, 2011:859 - 862.

[10]Mcnichol K S. Electronic Commerce. [J]. Americanriskandinsuranceassociation Inc, 2001, :68(:2):18-27. 
[11]Randeree K. Strategy, policy and practice in the nationalisation of human capital: 'project emiratisation'. [J]. Singaporehumanresourcesinstitute \& Curtinuniversityoftechnology, 2009, :17(:1):71-91.

[12]Houston, Douglas A. Can the Internet promote open global societies? [J]. Independent Review, 2003, 7(January). 